\title{
Analisis Faktor Adopsi Inovasi Perikanan Budidaya Karamba Jaring Apung di Waduk Cirata
}

\author{
Analysis of Innovation Adoption Factors \\ of Floating Net Cage Aquaculture in Cirata Reservoir
}

\author{
Atikah Nurhayati ${ }^{1}$, Titin Herawati ${ }^{1}$
}

${ }^{1}$ Faculty of Fisheries and Marine Science, Padjadjaran University

\begin{abstract}
Cirata Reservoir has a derivative function for the aquaculture floating net cage. Development of floating net cage technology in Cirata Reservoir undergoes several phases of floating net cage construction. This research aims to analyze the adoption factor of fishery innovation of floating net cage aquaculture. The research method used was a survey method with respondent technique using cluster random sampling based on floating net cage construction. Data collection techniques used were field research and library Research. This research used a data analysis tool called multiple linear regressions to measure the influence of one variable on another variable with SPSS. The variables in this research were measured using likert scale with internal and external factor parameters from floating net cage cultivators. This research was conducted in January-June 2017, located in Cirata Reservoir of Cianjur district, West Java Province. The primary data collection stage was from January-April 2017 and secondary data in May-June 2017. Based on the results of the research, development floating net cage construction of Cirata Reservoir undergoes three phases of construction change of floating net cage usage. The first phase is traditional, using bamboo construction; the second phase, semi-modern, using mixed construction between bamboo and stereofoam; and the third phase, modern, using fiber construction. Factors influencing the adoption of innovation include internal and external factors of floating net cage cultivators, partially internal factors influencing the adoption of innovation and absolutely external factors affecting the development of floating net cage innovation adoption. It can be concluded that the factors influencing the development of adoption of floating net cage aquaculture innovation are internal and external factors. Existing condition of floating net cage amount needs to be rearranged by using environmentally friendly construction. This research suggests to local governments to review the development of the number of floating net cage in Cirata Reservoir.
\end{abstract}

Keywords: Adoption of innovation, Cirata, Floating Net Cage, Aquaculture.

\begin{abstract}
Abstrak
Waduk Cirata memiliki fungsi turunan untuk perikanan budidaya Karamba Jaring Apung (KJA). Perkembangan teknologi KJA di Waduk Cirata mengalami beberapa fase perubahan konstruksi KJA.Penelitian ini bertujuan untuk menganalisis faktor adopsi inovasi perikanan budidaya KJA. Metode penelitian menggunakan metode survei dengan teknik pengambilan responden menggunakan cluster random sampling berdasarkan jenis kontruksi KJA. Tehnik pengumpulan data yang digunakan adalah penelitian lapangan dan penelitian kepustakaan. Alat analisis data yang digunakan dalam penelitian ini menggunakan regresi liner berganda, digunakan untuk mengukur pengaruh antara lebih dari satu variabel prediktor (variabel bebas) terhadap variabel terikatdengan menggunakan software SPSS.Variabel yang diukur dalam penelitian ini menggunakan skala nominal, ordinal dan interval dengan parameter faktor internal dan eksternal dari pembudidaya KJA. Penelitian ini dilaksanakan pada bulan JanuariJuni 2017, berlokasi di Waduk Cirata Kabupaten Cianjur Provinsi Jawa Barat.Tahap pengumpulan data primer pada bulan JanuariApril 2017 dan data sekunder pada bulan Mei-Juni 2017. Berdasarkan hasil penelitian perkembangan kontruksi KJA di Waduk Cirata mengalami tiga fase perubahan konstruksi penggunaan KJA.Fase pertama bersifat tradisional dengan menggunakan kontruksi bambu, fase kedua semi moderen dengan menggunakan kontruksi campuran antara bambu dan streofom, dan fase ketiga moderen dengan menggunakan kontruksi fiber. Faktor yang mempengaruhi adopsi inovasi meliputi faktor internal dan eksternal pembudidaya KJA, secara parsial faktor internal mempengaruhi adopsi inovasi dan secara absolut faktor eksternal mempengaruhi perkembangan adopsi inovasi KJA. Dapat disimpulkan bahwa faktor yang mempengaruhi perkembangan adopsi inovasi perikanan budidaya KJA yaitu faktor internal dan eksternal. Kondisi eksisting jumlah KJA perlu dilakukan penataan ulang dengan menggunakan jenis KJA yang ramah lingkungan. Penelitian ini menyarankan kepada pemerintah daerah untuk melakukan kaji ulang terhadap perkembangan jumlah KJA di Waduk Cirata.
\end{abstract}

Kata kunci : Adopsi inovasi, Cirata, KJA, Perikanan Budidaya

\footnotetext{
${ }^{1}$ Korespondensi penulis

E-mail: nurhayati_atikah@yahoo.co.id
} 


\section{Pendahuluan}

Waduk Cirata ini memiliki fungsi utama sebagai Pembangkit Listrik Tenaga Air (PLTA) untuk wilayah Jawa - Bali. Adapun fungsi lain dari waduk ini adalah sebagai daerah pariwisata dan tempat budidaya ikan. Kegiatan budidaya ikan yang banyak dikembangkan adalah budidaya ikan sistem Karamba Jaring Apung (KJA). Sifat perairan waduk yang dianggap sebagai common property dan open access menyebabkan pertumbuhan KJA di berbagai tempat berkembang sangat pesat dan cenderung tidak terkontrol dan tak terkendali. Pemanfaatan Waduk Cirata sebagai lokasi untuk budidaya ikan dengan sistem KJA telah berkembang sangat pesat.

Berdasarkan SK Gubernur Jawa Barat No. 41 Tahun 2002, jumlah jaring apung di Waduk Cirata dibatasi sebanyak 12.000 unit. Namun demikian, sampai pertengahan tahun 2017 jumlah tersebut telah meningkat 56.000 unit. Bila pembatasan jumlah unit jaring apung di Cirata tersebut didasarkan pada daya dukung (carrying capacity) perairan, maka diduga bahwa sudah terjadi kelebihan keramba jaring apung di Waduk Cirata.

Kegiatan proses produksi perikanan budidaya dengan sistem karamba jaring apung mengalami beberapa fase perubahan sesuai dengan kondisi ekologi, teknologi, ekonomi, sosial dan aturan yang berlaku dalam pengelolaan waduk Cirata (Nurhayati,A. 2014). Kondisi ekologi yang cenderung menurun, khususnya kualitas perairan umum Cirata. Proses produksi budidaya ikan KJA mengalami fase perkembangan dalam penggunaan input produksi dimulai dari kontruksi KJA, penggunaan benih ikan dan penggunaan pakan buatan. Adopsi inovasi merupakan suatu proses mental atau perubahan perilaku baik yang berupa pengetahuan (cognitive), sikap (affective), maupun keterampilan (psycomotor) pada diri seseorang sejak mengenal inovasi (Rogers and Shoemaker, 1971). Menurut Kottler (2003) inovasi sebagai barang, jasa, ide dan teknologi yang dianggap baru oleh seseorang atau kelompok masyarakat.

Menurut Satria (2002), perubahan teknologi perikanan secara antropologis sebagai suatu perubahan kebudayaan. Perubahan teknologi dapat terjadi melalui adopsi atau inovasi. Dalam suatu proses inovasi, penemuan baru seorang individu berupa alat dalam masyarakat disebut discovery, jika penemuan itu diakui dan diterima masyarakat, baru disebut invention, antara discovery dan invention membutuhkan waktu lama, karena masyarakat akan memastikan dulu kemanfaatan suatu temuan teknologi baru tersebut.

Perkembangan teknologi budidaya ikan KJA yang dimulai dari penggunaan input sampai dengan output produksi khususnya pembuatan kontruksi KJA sebagi media tempat membudidayakan ikan, memerlukan tingkat kemudahan untuk dilakukan oleh pembudidaya dengan memperhatikan ketersediaan sumber modal, sehingga teknologi yang baru bisa diterapkan dengan memperhatikan sistem sosial kemasyarakatan (Nurhayati, 2013).

Rogers dan Shoemaker (1971) menjelaskan bahwa proses difusi merupakan bagian dari proses perubahan sosial. Perubahan sosial adalah proses dimana perubahan terjadi dalam struktur dan fungsi sistem sosial. Perubahan sosial terjadi dalam tiga tahapan, yaitu: penemuan (invention), difusi (diffusion), dan konsekuensi (consequences).

Proses difusi inovasi memerlukan proses komunikasi melalui seseorang yang disebut komunikator menyampaikan stimulus berupa isi atau pesan yang memiliki tujuan mengubah atau membentuk perilaku orang lain (Hovland, Janis \& Kelley, 1953). Saluran komunikasi merupakan salah satu elemen penting dalam menentukan keberhasilan difusi adopsi inovasi untuk diterima oleh khalayak sasaran.

Proses komunikasi penyuluhan untuk pelaku pembudidaya perikanan air tawar diukur berdasarkan kemampuan responden dalam memanfaatkan fasilitas transformasi informasi teknologi, melalui interaksi sosial, serta tingkat kemampuan mengelola kegiatan proses produksi perikanan budidaya akan menentukan tingkatan adopsi inovasi. (Nurhayati, 2015)

Proses difusi inovasi terdapat empat elemen pokok, yaitu: (1) Inovasi merupakan gagasan, tindakan, atau barang yang dianggap baru oleh seseorang, dalam hal ini, kebaruan inovasi diukur secara subjektif menurut pandangan individu dan kelompok yang menerimanya; (2) saluran komunikasi merupakan alat untuk menyampaikan pesan-pesan inovasi dari sumber 
kepada penerima pesan, dalam memilih saluran komunikasi, sumber perlu memperhatikan hal hal sebagai berikut yaitu:tujuan diadakannya komunikasi dan karakteristik penerima komunikasi. Jika sasaran komunikasi dimaksudkan untuk memperkenalkan suatu inovasi kepada khalayak yang banyak dan tersebar luas, maka saluran komunikasi yang lebih tepat, cepat dan efisien, adalah media massa. Tetapi jika komunikasi dimaksudkan untuk mengubah sikap atau perilaku penerima secara personal, maka saluran komunikasi yang paling tepat adalah saluran interpersonal; (3) jangka waktu merupakan proses keputusan inovasi, dari mulai seseorang mengetahui sampai memutuskan untuk menerima atau menolaknya, dan pengukuhan terhadap keputusan ini sangat berkaitan dengan dimensi waktu. Paling tidak dimensi waktu terlihat dalam proses pengambilan keputusan inovasi, keinovatifan seseorang, relatif lebih awal atau lebih lambat dalam menerima inovasi, dan kecepatan pengadopsian inovasi; (4) sistem sosial merupakan kumpulan unit yang berbeda secara fungsional dan terikat dalam kerjasama untuk menyelesaikan masalah dalam rangka mencapaitujuan bersama,(Rogers,2003). Terdapat lima tahapan dalam proses adopsi inovasi yaitu tahap kesadaran, minat, penilaian, percobaan dan penerimaan. Berdasarkan waktu yang dibutuhkan untuk menyelesaikan seluruh proses adopsi dari tahapan di atas, terdapat lima golongan yaitu golongan pelopor atau sering disebut dengan inovator, golongan pengetrap awal disebut dengan early adopter, golongan pengetrap awal dalam jumlah yang banyak disebut eraly majority, pengetrap akhir disebut dengan late majority dan golongan penolak disebut dengan laggard.

Proses adopsi inovasi merupakan rangkaian dalam pengambilankeputusanmelaluitahapansebagaiberikut: tahap deterministik, pada tahap ini variabel-variabel yang mempengaruhi keputusan perlu didefinisikan dan saling meng hubungkan, sehingga dilakukan penetapan nilai, dan selanjutnya tingkat kepentingan variable diukur, tanpa terlebih dahulu memperhatikan unsur ketidakpastiannya; tahap probabilistik, penetapan besarnya ketidakpastian yang melingkupi variabelvariabel yang penting, dan menyatakannya dalam bentuk suatu nilai. Dalam tahapan ini juga dilakukan penetapan preferensi atas risiko, tahap informasional, intinya adalah meninjau kembali dari hasil dua tahap sebelumnya guna menentukan nilai ekonomisnya bila kita ingin mengurangi ketidakpastian suatu variabel yang dirasakan penting. (Mangkusubroto \&Trisnadi, 1987)

Perkembangan inovasi teknologi penggunaan input produksi dalam perikanan budidaya karamba jaring apung mengalami perubahan dari tahun ke tahun seperti perubahan kontruksi karamba jaring apung, mulai dari menggunakan kontruksi bambu, kemudian mengalami perubahan menggunakan sterofom dan yang terakhir menggunakan fiber. Selain itu tahapan perubahan dalam penggunaan pakan buatan dengan menggunakan berbagai komposisi isi pakan dan tingkat kandungan protein yang berbeda, perubahan penggunaan pakan tersebut dipengaruhi oleh beberapa faktor diantaranya harga pakan, jenis ikan dan kualitas pakan termasuk tahapan perubahan penggunaan jarring dimulai dari penggunaan jaring satu lapis (singgle net) sampai dengan penggunaan jaring berlapis (doubble net). Berdasarkan perkembangan inovasi teknologi perikanan budidaya dengan menggunakan sistem KJA perlu dilakukan penelitian untuk menganalisis faktor adopsi inovasi yang berpengaruh terhadap perkembangan teknologi perikanan budidaya sistem KJA.

\section{Metode Penelitian}

Penelitian ini dilaksanakan pada bulan Januari-Juni 2017, berlokasi di Waduk Cirata Kabupaten Cianjur Provinsi Jawa Barat. Tahap pengumpulan data primer bulan Januari-April 2017 dan data sekunder bulan Maret-Agustus 2017. Metode penelitian menggunakan metode survei dengan tehnik pengambilan responden menggunakan cluster random sampling berdasarkan jenis kontruksi KJA dengan jumlah 40 responden yaitu kelompok pembudidaya ikan KJA yang menggunakan singgle net sebanyak 20 responden dan kelompok pembudidaya ikan KJA yang menggunakan doubble net sebanyak 20 responden. Alat analisis data yang digunakan dalam penelitian ini menggunakan regresi liner berganda. Menurut Effendi, 1989 skala Likert, yaitu cara pengukuran dengan menghadapkan seorang responden dengan sebuah pertanyaan dan kemudian diminta untuk memberikan jawaban: sangat setuju (5), setuju (4), ragu-ragu (3), tidak tahu (2), sangat tidak tahu (1), jawaban tersebut diberi skor 1 sampai dengan 5. Analisis Regresi Linear Berganda digunakan untuk mengukur pengaruh antara lebih dari satu variabel 
prediktor (variabel bebas) terhadap variabel terikat:

$$
Y=a+b_{1} x_{1}+b_{2} x_{2}+b_{3} x_{3+} b_{4} x_{4}+b_{n} x_{n}
$$

Keterangan:

$\begin{array}{ll}\mathrm{Y} & : \text { Variabel dependen/terikat } \\ \mathrm{A} & : \text { Konstanta } \\ \mathrm{b}_{1}, \mathrm{~b}_{2} & : \text { Koefisien Regresi } \\ \mathrm{X}_{1}, \mathrm{X}_{2} & : \text { Variabel Bebas }\end{array}$

\section{Hasil dan Pembahasan}

Waduk Cirata merupakan salah satu waduk yang dibangun di Daerah Aliran Sungai (DAS) Citarum. Waduk Cirata ini memiliki fungsi utama sebagai Pembangkit Listrik Tenaga Air (PLTA) untuk wilayah Jawa - Bali. Adapun fungsi lain dari waduk ini adalah sebagai daerah pariwisata dan tempat budidaya ikan. Kegiatan budidaya ikan yang banyak dikembangkan adalah budidaya ikan sistem Karamba Jaring Apung (KJA).

Budidaya ikan KJA yang dilakukan oleh masyarakat pada awalnya untuk menggantikan lahan masyarakat yang terkena pembangunan waduk serbaguna. Pemanfaatan waduk sebagai perairan umum untuk budidaya ikan KJA pada prinsipnya diperbolehkan dengan catatan tidak melebihi batas ambang luasan waduk dan tidak menggangu fungsi utama waduk sebagai pembangkit listrik tenaga air.

Budidaya ikan KJA yang dilakuakan oleh masyarakat sebagai pe;aku usaha pembudidaya ikan tentu berorientasi pada nilai ekonomi dengan menjaga keberlangsungan lingkungan perairan umum. Proses penggunaan input produksi yang digunakan mengalami kecenderungan perubahan yang meningkat pada setiap siklus dengan kondisi tingkat kualitas air yang semakin menurun. Pembudidaya dihadapkan pada pilihan pengambilan keputusan dalam teknologi yang digunakan sepertiperubahan kontruksi karamba jaring apungdalam menggunakan jenis jarring tipe singgle net atau duble net serta jenis pakan yang digunakan.

Proses pengambilan keputusan pembudidaya ikan dalam menerapkan teknologi dilihat dari faktor internal dan eksternal. Berdasarkan hasil penelitian karakteristik responden yang meliputi tingkat usia produktif sebanyak 35 responden (87,5\%) berkisar antara 30 sampai dengan 64 tahun. Tingkat usia berkaitan dengan kemampuan proses belajar dari pembudidaya yang mempengaruhi dalam melakukan suatu kegiatan. Menurut Latifah et al. (2010) menyatakan bahwa semakin bertambah usia seseorang, maka akan semakin banyak alternatif cara yang dilakukan untuk menghadapi permasalahan yang dialaminya. Salah satunya pengambilan keputusan dalam menerapkan teknologi.

Kepemilikan usaha KJA berdasarkan tingkat pengalaman dalam melakukan usaha budidaya perikanan sistem KJA lebih dari 20 tahun sebanyak 30 responden (75\%) dan kurang dari 20 tahun sebanyak 10 responden $(25 \%)$. Berdasarkan hasil penelitian tingkat pengalaman yang dimiliki oleh pembudidaya sangat menentukan pilihan pengambilan keputusan dalam menerapkan input produksi.

Tingkat pendidikan formal responden sebanyak 10 responden $(0,25 \%)$ lulusan SLTA, 15 responden $(37,5 \%)$ lulusan SLTP, 15 responden $(37,5 \%)$ lulusan

SD. Tingkat pendidikan seseorang dapat mengubah pola pikir, daya penalaran yang lebih baik, sehingga makin lama seseorang mengenyam pendidikan akan semakin rasional dalam melakukan pengambilan keputusannya.

Berdasarkan hasil penelitian perkembangan kontruksi KJA di Waduk Cirata mengalami tiga fase perkembangan konstruksi penggunaan KJA. Fase pertama bersifat tradisional dengan menggunakan kontruksi bambu, fase kedua semi moderen dengan menggunakan kontruksi campuran antara bambu dan streofom, dan fase ketiga moderen dengan menggunakan kontruksi fiber. Pengambilan keputusan merupakan suatu hasil atau keluaran dari proses mental atau kognitifyang membawa pada pemilihan suatu jalur tindakan di antara beberapa alternatif yang tersedia. Pembudidaya KJA memutuskan untuk menerima atau menolak inovasi melalui tahapan pengetahuan, persuasi, keputusan, implementasi dan konfirmasi.

Proses pengambilan keputusan inovasi mencakup tahap munculnya pengetahuan (Knowledge) yaitu ketika seorang individu khususnya pembudidaya ikan diarahkan untuk memahami eksistensi dan keuntungan atau manfaat dari inovasi teknologi yang disampaikan 
melalui tahapan pengetahuan dari suatu inovasi, tahap persuasi (Persuasion) ketika seorang individu khususnya pembudidaya membentuk sikap baik atau tidak baik dari inovasi teknologi yang akan diterapkan, tahap keputusan (Decisions) muncul ketika seorang individu atau pembudidaya ikan terlibat dalam aktivitas yang mengarah pada pemilihan adopsi atau penolakan sebuah inovasi akan diterapkan, tahapan implementasi (Implementations), ketika sorang individu atau pembudidaya ikan menetapkan penggunaan suatu inovasi, tahapan konfirmasi (Confirmations), ketika seorang individu atau pembudidaya ikan mencari penguatan terhadap keputusan penerimaan atau penolakan inovasi yangsudah dibuat sebelumnya.

Keputusan untuk mengadopsi teknologi oleh pembudidaya ikan KJA lebih memperhatikan aspek kesesuaian terutama yang terkait dengan sumberdaya yang dimiliki oleh pembudidaya KJA diantaranya kontruksi KJA, sumber modal, tenaga kerja, jenis ikan yang dibudidayakan, jenis pakan dengan cara yang mudah dan terjangkau.

Keramba jaring apung merupakan salah satu metode pemeliharan ikan dalam kurungan yang terdiri atas empat pola dasar pemeliharan ikan, yaitu :

1. Kurung tancap merupakan bentuk kurungan ikan yang peletakannya menggunakan tiang-tiang pancang yang ditancapkan ke dasar perairan.

2. Kurungan terendam merupakan bentuk kurungan ikan yang secara keseluruhan terendam didalam air dan bergantung kepada pelampung/rangka apung.

3. Kurungan lepas dasar yang biasanya terbuat dari kotak kayu/bambu dan diletakan pada dasar air yang beraliran deras, dan diberi pemberat/jangkar.

4. Jaring kurung apung ini terikat pada suatu rangka yang didukung oleh pengapung.

Berdasarkan hasil penelitian karamba jaring apung di Waduk Cirata mempunyai luas permukaan tiap petaknya $7 \times 7 \mathrm{~m}^{2}$ dan kedalamannya bervariasi antara 2-3 m, biasanya para pembudidaya ikan menggunakan 4 petak atau sama dengan 1 unit untuk budidaya ikan (Garno\& Adibroto,1999). Tahapan adopsi inovasi kontruksi KJA diawali dengan menggunakan kontruksi dari bambu mulai tahun 1990 sampai dengan sekarang pada saat penelitian dilakukan.

Pelampung terbuat dari drum plastik atau drum besi bervolume 200 liter, Styrofoam atau gabus yang dibungkus dengan kain terpal yang berfungsi untuk mempertahankan kantong jaring tetap mengapung didekat permukaan air. Jenis jarring yang digunakan pada awalnya satu lapis (single net) kemudian berkembang menjadi dua lapis (double net) sekitar tahun 1995.Keramba jaring apung idealnya ditempatkan pada perairan yang memiliki kedalaman lebih dari 2 meter.

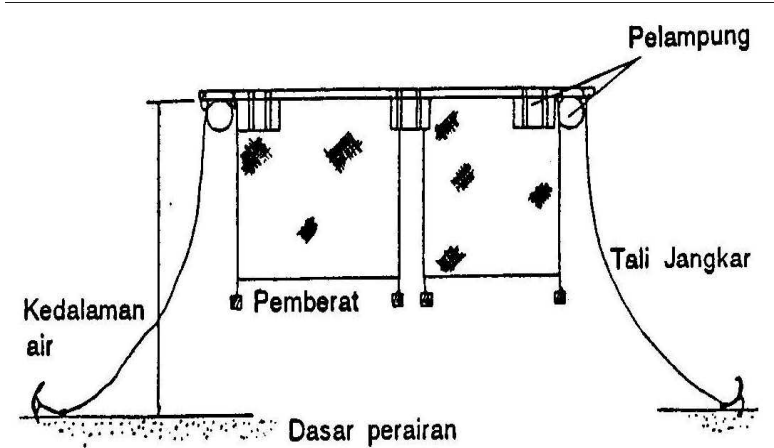

Gambar 1, Konstruksi KJA

Keramba jaring apung merupakan sistem budidaya dalam wadah berupa jaring yang mengapung dengan bantuan pelampung dan ditempatkan pada perairan di waduk Cirata. Sistem ini terdiri atas beberapa komponen yaitu rangka, kantong jaring, pelampung, jalan inspeksi, dan rumah jaga. Perkembangan inovasi teknologi kontruksi KJA mengalami pergeseran dengan menggunakan fiber pada tahun 2010, dengan melakukan percontohan dari Balai Pelestarian Pengelolaan Perairan dan Ikan Hias Provinsi Jawa Barat.

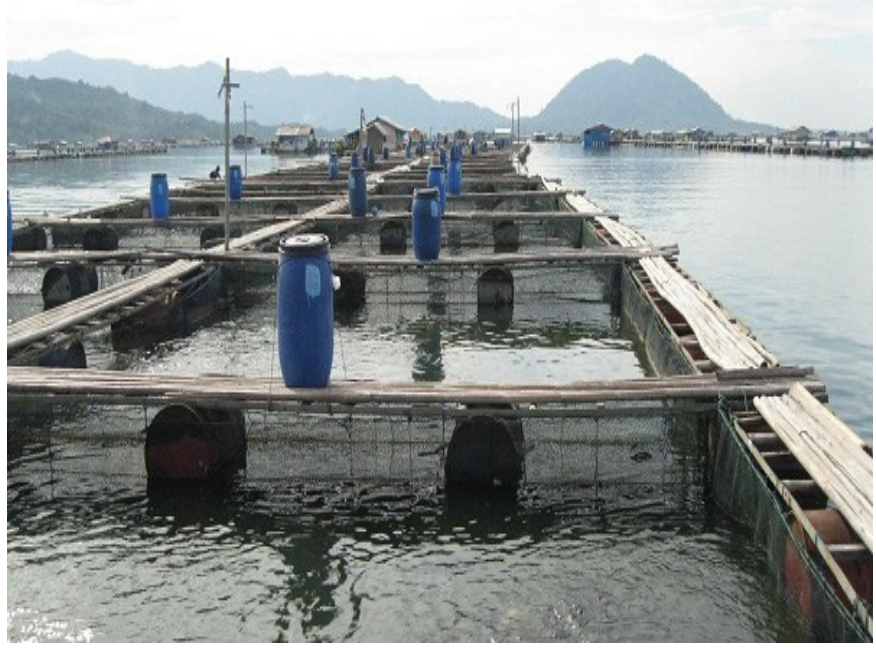

Gambar 2. Kontruksi Bambu KJA 
KJA yang dipakai biasanya terdiri dari dua lapis jaring, lapis pertama terdiri dari 4 jaring dengan ukuran $7 \times 7 \times 2,5 \mathrm{~m}^{3}$ atau $3 \times 3 \times 3 \mathrm{~m}^{3}$ biasa digunakan untuk memelihara ikan mas dan lapis kedua merupakan 1 jaring dengan ukuran 15,8x15,8x5 $\mathrm{m}^{3}$ biasa digunakan untuk memelihara ikan nila. Jaring yang dipakai terbuat dari bahan polyethilen (PE) D.18 dengan mesh size (lebar mata jaring) antara 0,75-1 cm (Departemen Kelautan dan Perikanan 2003).

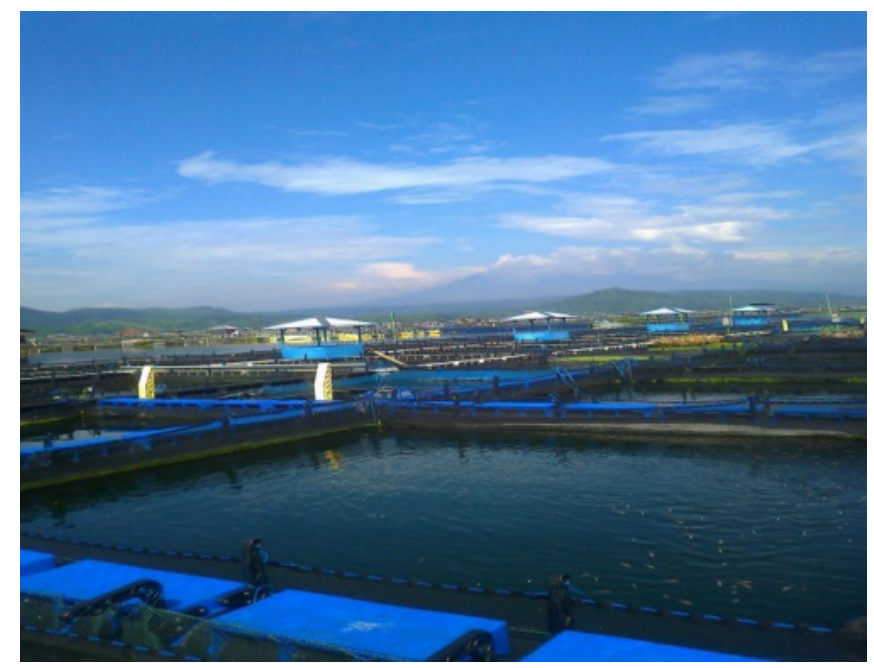

Gambar 2. Kontruksi Fiber KJA

Pembudidaya ikan KJA melakukan proses adopsi inovasi perkembangan penggunaan konstruksi KJA. Faktor yang mempengaruhi adopsi inovasi meliputi faktor internal dan eksternal pembudidaya KJA. Faktor internal yang mempengaruhi adopsi inovasi yaitu kepemilikan usaha budidaya KJA yang meliputi umur $\left(\mathrm{X} 1_{.1}\right)$, pendidikan $\left(\mathrm{X} 1_{.2}\right)$, pengalaman usaha $\left(\mathrm{X} 1_{.3}\right)$ dan modal usaha $\left(\mathrm{X} 1_{4}\right)$, sedangkan faktor eksternal meliputi, peran lembaga keuangan formal, (X2..) peran lembaga keuangan non formal, $\left(\mathrm{X} 2 ._{2}\right)$, pemilik kja $\left(\mathrm{X} 2 ._{3}\right)$, peranan dinas perikanan $\left(\mathrm{X} 2 ._{4}\right)$, dan tenaga kerja KJA (X2. $\left.{ }_{5}\right)$.

Berdasarkan hasil penelitian dengan menggunakan analisis regresi linear berganda diperoleh nilai koefisien determinasi $\left(\mathrm{R}^{2}\right)$ memiliki nilai 71,52 artinya faktor internal dan eksternal mampu menjelaskan faktor faktor yang mempengaruhi perkembangan adopsi inovasi pada usaha budidaya KJA sebesar 71,52\% sedangkan 28,48 \% merupakan faktor lain yang tidak dilakukan dalam penelitian ini

Berdasarkan nilai parsial dari masing masing variabel ada faktor internal dan eksternal melalui uji T.Faktor internal yang mempengaruhi adopsi inovasi usaha perikanan budidaya KJA memiliki nilai $\mathrm{t}$ hitung $>\mathrm{t}$ tabel $(1,92)$ masing masing yaitu sebagai berikut: umur $\left(\mathrm{X} 1_{._{1}}\right.$ ) dengan nilai $\mathrm{t}_{\text {hitung }}$ 2,15 artinya tingkat kecepatan penerapan adopsi inovasi kontruksi KJA dan alternatif penggunaan pakan buatan dipengaruhi oleh umur tenaga kerja pembudidaya ; pendidikan $\left(\mathrm{X} 1 .{ }_{2}\right)$ dengan nilai $\mathrm{t}$ hitung 2,17 artinya pendidikan memiliki pengaruh terhadap perkembangan adopsi inovasi dalam melakukan kegiatan usaha perikanan budidaya KJA termasuk penggunaan input produksi; pengalaman usaha $\left(\mathrm{X} 1 ._{3}\right)$ dengan nilai $\mathrm{t}{ }_{\text {hitung }} 2,59$ artinya pengalaman usaha pembudidaya KJA memiliki pengaruh terhadap perkembangan dan penerapan inovasi yang baru dalam usaha perikanan budidaya KJA dan modal usaha (X1.. ) memiliki nilai $t_{\text {hitung }} 3,12$ artinya modal memiliki pengaruh terhadap penerapan inovasi yang baru untuk usaha budidaya KJA.

Faktor eksternal memiliki nilai $\mathrm{t}_{\text {hitung }}>\mathrm{t}$ tabel $(1,92)$ dimana peran lembaga keuangan formal, (X2.. ) memilki nilai $t{ }_{\text {hitung }} 4,12$ artinya peran lembaga keuangan formal dalam perkembangan penyedian input produksi memiliki pengaruh terhadap adopsi inovasi budidaya KJA; peran lembaga keuangan non formal (X2.2) memiliki nilai $t_{\text {hitung }} 3,15$ artinya dalam menjalankan usaha budidaya KJA keberadaan lembaga keuangan non formal mempengaruhi penentuan penggunaan inovasi yang baru; pemilik kja (X2. ${ }_{3}$ ) memiliki nilai $t_{\text {hitung }} 6,17$ artinya pemilik KJA memiliki kewenangan penuh dalam menentukan setiap tahapan perkembangan inovasi yang akan diadopsi dalam usaha budidaya KJA; peranan dinas perikanan (X2. ${ }_{4}$ memiliki nilai $t$ hitung, 2 , artinya peran dari dinas perikanan melalui penyuluhan yang dilakukan secara berkala akan memberikan pengaruh terhadap informasi yang diterima oleh pembudidaya mengenai perkembangan inovasi perikanan budidaya KJA dan tenaga kerja $\mathrm{KJA}\left(\mathrm{X} 2{ }_{5}\right)$ memiliki nilai $\mathrm{t}_{\text {hitung }}$ 2,10 artinya tenaga kerja KJA sebagai ujung tombak dalam menerapkan perkembangan adopsi inovasi memiliki pengaruh terhadap inovasi yang diterapkan dalam sistem perikanan budidaya KJA.

Berdasarkan nilai absolut dengan menggunakan uji $\mathrm{F}$ bahwa nilai $\mathrm{F}_{\text {hitung }} 21,09>\mathrm{F}_{\text {tabel }} 3,45$ artinya secara absolut atau keseluruhan variabel yang dilakukan dalam penelitian ini baik faktor internal dan eksternal 
mempengaruhi perkembangan adopsi inovasi KJA di perairan umum Waduk Cirata.

Berdasarkan hasil penelitian inovasi akan mudah diterima oleh pembudidaya ikan apabila inovasi tersebut sesuai dengan kebutuhan pembudidaya untuk dapat memecahkan permasalahan yang dihadapi oleh pembudidaya ikan seperti kontruksi KJA dan perkembangan alternatif pakan buatan. Hal pertama yang dilihat oleh pembudidaya ikan dalam mengadopsi suatu inovasi adalah keuntungan yang akan diperoleh adopteryaitu pembudidaya ikan. Keselaran inovasi dengan kebiasaan, pengalaman dan nilai-nilai yang dimiliki oleh pembudidaya ikan KJA menjadi tolak ukur dalam mengadopsi. Inovasi teknologi seperti kontruksi KJA yang terbuat dari fiber diharapakan mampu diterapkan oleh pembudidaya ikan KJA, namun kondisi ini tidak bisa di adosi karena memerlukan biaya investasi yang cukup besar.

Rekomendasinya perlu dilakukan kerjasama antara pabrik pembuat KJA dari fiber dengan pembudidaya KJA dan Dinas Kelautan dan Perikanan melalui sistem kredit investasi atau sistem kemitraan, sistem bagi hasil atau sistem hamparan berdasarkan kesepakan bersama antara pemilik modal dan pengguna investasi sehingga tercipta iklim kemitraan yang saling menguntungkan untuk semua pihak. Perkembangan adopsi inovasi teknologi memiliki keterkaitan dengan sosial budaya.

Pembudidaya mengalami proses adopsi inovasi dengan cara merubah kebiasaan dalam menggunakan input produuksi secara bertahap kearah inovasi yang menciptakan efisiensi teknis dan ekonomis. Inovasi terjangkau oleh pembiayaan atau sumber modal yang dimiliki oleh pembudidaya KJA dengan mitra modal, sederhana, tidak rumit dan mudah dilaksanakan. Kemudahansuatu teknologi menjadi prioritas bagi pembudidaya KJA, untuk mengadopsi suatu inovasiyang mudah akan banyak adopter yang mampu menggunakannya denganmeniru tata pelaksanaannya tanpa bertanya kepada para ahlinya.

Rogers (2003) menyatakan bahwa pengelompokan adopter terdiri dari: Inovators, Early Adopter, Early Mayority, Late Mayority dan Laggard. Inovators merupakan pemilik dan pembudidaya KJA yang secara aktif mencari gagasan baru dan bersifat dinamis dalam menggunakan input produksi sekitar $1,5 \%$ pembudiaya KJA yang pertama kali mengadopsi inovasi tergolong kepada jenis innovators dengan ciri-cirinya yaitu: berani mengambil resiko, memiliki sumber modal yang kuat, early adopters merupakan tipe pembudidaya yang memiliki KJA dan kepedulian untukmembantu dan mengembangkan sistem sosianya sekitar 28,5\% yang memiliki tipe early adopters yang menjadi para perintis dalam penerimaan perkembangan inovasi penggunaan input produksi, early majority merupakan tipe pembudidaya ikan KJA yang termasuk pengikut dalam pengambilan keputusan kelompoknya,tipe ini berkisar 34\% yang menjadi pengikut awal, late majority atau pengikut terakhir merupakan pembudidaya KJA yang mengikuti kelompoknya, saat seluruh anggota kelompok sudah mengadopsi suatu inovasi khususnya penggunaan input produksi dalam sistem budidaya KJA. Pengikut akhir ini berkisar 34\% dalam penerimaan inovasi, adapun ciri-ciri dari pengikut akhir ini adalah: skeptis, menerima karena pertimbangan ekonomi atau tekanan sosial, dan memiliki tingkat kehatihatian yang cukup tinggi dalam artian tidak tidak berani menanggung risiko dan terakhir adalah laggard keberadaan pengikut laggard atau individu yangpaling akhir menerima inovasi dalam penggunaan input produksi usaha budidaya KJA berkisar 16\% dalam suatu sistem sosialdengan cirinya yaitu tradisional, wawasan terbatas, bukan opinion leaders, keterbatasan sumber modal.

Perkembangan adopsi inovasi perikanan budidaya KJA diperlukan keterlibatan seluruh stakeholder termasuk campur tangan pemerintah daerah untuk mengelola sumberdaya perikanan di perairan umum secara berkelanjutan. Kondisi eksisting jumlah KJA perlu dilakukan penataan ulang dengan menggunakan kontruksi yang ramah lingkungan. Penelitian ini menyarankan kepada pemerintah daerah untuk melakukan kaji ulang terhadap perkembangan jumlah KJA di Waduk Cirata

\section{Kesimpulan}

Perkembangan kontruksi KJA di Waduk Cirata mengalami tiga fase perubahan konstruksi penggunaan KJA.Fase pertama bersifat tradisional dengan menggunakan kontruksi bambu, fase kedua semi moderen dengan menggunakan kontruksi campuran antara bambu dan streofoam, dan fase ketiga moderen dengan menggunakan kontruksi fiber. Faktor yang mempengaruhi perkembangan adopsi inovasi 
perikanan budidaya KJA yaitu faktor internal dan eksternal

\section{Daftar Pustaka}

Effendi,Sofian. 1989. Prinsip-prinsip Pengukuran dan Penyusunan Skala. (Editor) dalam Metodologi Penelitian Survai.LPES. Jakarta

Hamid,A.1999.Pengembangan Masyarakat Nelayan dan Kemaritiman (Suatu studi Sosial Antropologi Ekonomi).PPs. UNM. Makassar

Indrianingsih,K.S. 2011. Pengaruh Penyuluhan Terhadap Keputusan Petani Dalam Adopsi Inovasi Teknologi Usahatani Terpadu. Jurnal Agro Ekonomi, 29(1),1-24

Mardikanto T. 2009. Sistem Penyuluhan Pertanian. Surakarta: UNS Press

Nurhayati,A.2013. Analisis Kebijakan Pemerintah Daerah Dalam Mendukung Pengelolaan Perikanan Budidaya AirTawar Melalui Sistem Karamba Jaring Apung. Proseding Semnaskan UGM 2013.

Nurhayati,A.2014. Analisis Komparatif Nilai Ekonomi Pengelolaan Budidaya Ikan Karamba Jaring Apung (Studi Kasus di KJA Cirata, Kabupaten Cianjur Provinsi Jawa Barat) Seminar Nasional Ikhtiologi Indonesia VIII.IPB, Bogor.

Nurhayati,A. 2014. Resource Managemnet Analysis of Aquaculture Sustainability (The Case Study at Floating Net Cages Reservoir Cirata. Proccedings Sustainability Science Symposium ,2014. Program Pasca Sarjana Ilmu Lingkungan. Unpad.

Oktavia.,dkk.2017. Hubungan Perilaku Komunikasi dan Pengembangan Kapasitas Pelaku Agribisnis Perikanan Air Tawar di Padang, Sumatera Barat. Jurnal Penyuluhan, September 2017 Vol. 13 No. 2

Rogers dan Schoemaker. 1986. Memasyarakatkan Ideide Baru. Penerbit Usaha Nasional Surabaya.

1971.Communication of Innovation: A Cross Cultural Approach. New York : The Free Press.

Rogers. EM. 2003. Diffusion of Innovations. 5th ed. New York: Free Pres.

Satria,A. 2002. Pengantar Sosiologi Masyarakat Pesisir. Pustaka Cidesindo. Jakarta.

Van den Ban, A.W, dan H.S. Hawkins. 2001. Penyuluhan Pertanian. Yogyakarta: Kanisius

\section{Ucapan Terimakasih}

Penelitian dapat terlaksana berkat adanya bantuan dana penelitian Hibah Unggulan Internal Universitas Padjadjaran tahun anggaran 2017 